\title{
Assessing the current problems in the tourism industry (case study: Tabriz city)
}

\author{
Sepideh Gorbaniye Golzari ${ }^{1}$, Karim Hosseinzadeh Dalir $^{2}$ and \\ Bashir Beyg Babayi ${ }^{3}$
}

1 Department of Geography and Urban Planning, Marand branch, Islamic Azad University, Marand, Iran E-mail: arlotfi@gmail.com 2 Department of Geography and Urban Planning, Marand branch, Islamic Azad University, Marand, Iran. E-mail: arlotfi@gmail.com 3 Department of Geography and Urban Planning, Malekan branch, Islamic Azad University, Malekan, Iran E-mail: arlotfi@gmail.com

\begin{abstract}
Today, tourism industry has a high status in the economies of the country and plays an active and effective role in promoting the economic, social and cultural structure of countries, especially in the developing countries. Although tourism is just one industry, tourism has the most cultural interactions. The tourism industry plays a major role in the growth process and this is where Iran has the right advantages. The present research which is descriptiveresearch, has been conducted using library practices and practical studies and, in addition to identifying strengths, examines the weaknesses of tourism growth in the current situation of Tabriz and the capabilities and limitations of tourism growth in the city and mentioned to matrix of external factors affecting the growth of tourism in Tabriz city. These results indicate the inadequacy of the urban transport system for the growth of urban tourism, low attention to cultural and artistic attractions, lack of adequate and adequate parking in the historical context, attention to urban furniture, as well as beatification of tourist attractions, lack of management and planning Suitable for tourism related issues by urban organizations.
\end{abstract}

Keywords: Tourism. Tourism services. Cultural problems. Urban tourism growth. Lack of growth in tourism industry.

\section{INTRODUCTION}

Today, tourism as a social, economic and cultural phenomenon is at the center of the attention of the countries and has been continuously expanding in the past decades. Modern tourism is associated with the growth process and has different goals. In this process, tourism becomes one of the main goals and characteristics of social and economic progress. The global expansion of tourism in industrialized countries has led to the expansion of economic and employment benefits in sectors related to cultural, agricultural and communications, etc. (UNWTO, 2012). Tourism is a dynamic phenomenon that experiences new activities, new destinations, new technologies, new markets and rapid changes (CSD, 1999). In planning for the growth of tourism, it is necessary to pay special attention to the growth of needs, characteristics and market demand as a factor, as well as current problems and management and the use of tourist attractions, tourism services and facilities as a supply factor for tourism. Considering the importance of tourism growth for the city of Tabriz, in order to utilize existing capacities and provide better services to tourists, we need to plan carefully to overcome the obstacles and problems encountered in the tourism development of Tabriz city (Gantly 2007). In fact, the most important goal of tourism growth is the eco- 
nomic and social growth of tourist areas (Sharply and Richard, 1977). Here, recognizing and evaluating the problems of urban tourism growth can have an important role in organizing and planning tourist spaces appropriate to the social, natural and cultural situation and using existing capacities. The growth of tourism is directly linked to the rise of standards of living and income of the people of the world, especially developing countries. Some of the major factors behind the expansion of tourism in some countries include economic expansion, rising people's income, the opening of political boun-daries, privatization of air transport and marketing. Tourism is a dynamic and competitive industry. Continuous adaptation of the main elements of the industry to the needs and desires of tourists is the natural part of this area.

\subsection{Importance and necessity of research}

At the world tourism conference held in Manil in 1980, the importance of tourism and its widespread influences was as follows: "Tourism is a major activity due to its direct effects on societies, culture, education, economics and international relations. In the lives of the people of the world" (Manil statement on global tourism, 1980). Today, urban tourism is a kind of competitive process in every community for its major cities, with its urban management by providing definitions, setting goals, judging between various options in the field of investment and establishing an appropriate management structure and commercializing urban tourism products in this area of activity. And for the sustained growth of the local community, it must take the necessary measures effectively. Iran is a major civiliza- tion with diverse tourist attractions and attractions and the specific climate of one of the seven civilized humanity countries and an important part of the Silk Road in Iran, besides demanding the economic benefits of the tourist industry Employment and income, emphasizes the preservation of transcendental values and the cultural and civilization identity which requires important actions in this area. Nowadays, many of the advanced countries in the world consider tourism as the best way to promote their culture, create international understanding and achieve high economic incomes (Kahnamoyi, 2004).

\subsection{Background research}

About 40 years ago, since the 1970s, tourism-related studies have gained a special status among other academic disciplines and have been raised as a major academic discipline (Graburn and Jafari, 1991). In this area, extensive studies have been done on the various tourism features and the number of these studies has always been added and it can be said that research in the field of tourism has increased considerably since the 1990s, especially after 2000. Assessing and reviewing articles, research and related books in the field of tourism over a period of 50 years suggests that, by the late 1970s, most of these studies were related to assessing the economic impact of tourism on economic growth in countries, but after this decade, social impacts, Cultural and environmental tourism has also received a lot of attention. In other words, researchers have found that a comprehensive assessment of tourism planning and growth is crucial to studying its economic effects alone (Heiydary, 2008). In this 
regard, Mr. Shojaeay and Nory (2007) have been evaluating government policies on the tourism industry and believe that they have created a policy gap in government programs.

Rakhshany and Zaraby (2009) have studied the problems and opportunities of ecotourism growth in Iran. They sought to identify effective barriers to attracting people interested in nature and provide appropriate strategies for ecotourism growth. Security and weakness of infrastructure facilities are among the most important barriers to the Iranian ecotourism. Nobakht and Piroz (1387) and Abasy et al. (1391) are investigating the obstacles and solutions of the tourism industry in Iran and emphasizing economic and infrastructural factors. In both researches, political, governmental and ideological factors have been neglected as one of the most important and fundamental changes in the tourism industry. From this research, it can be concluded that foreign research has emphasized on political and ideological factors, but has ignored these factors in internal investigations and has identified other factors such as security, economic and welfare factors as the most important factors in growth barriers. Tourism is introduced. Accordingly, the issue is felt by the necessity of conducting a research that can determine and explain the greater contribution of the barriers to tourism growth.
Figure 1 - Conceptual model of research

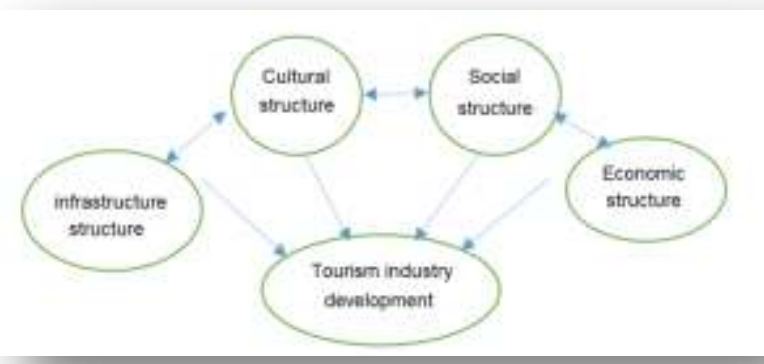

\section{METHODOLOGY}

\subsection{Research purposes}

Given the growth of tourism at the global level and its transformation into an industry, for scientific purposes, it is a science that generates wealth and employment and has a positive impact on psychological discussion and can ultimately be a factor in providing Growth is sustained, studied. The objectives of this research are:

- Identify the weaknesses of the city of Tabriz in the area of tourism development.

- Understanding the problems and dangers of the city of Tabriz in connection with the selection of Tabriz as the capital of tourism in Islamic cities.

- Provide solutions for tourism growth to prioritize this industry.

- Understanding the potential of the city of Tabriz as the tourism capital of islamic cities.

- Identify issues in the tourist city of Tabriz and provide solutions for tourism growth and prioritize this industry.

\subsection{Range of study}

The city of Tabriz has been one of the historical and cultural cities of its ancient civilization and has been one of the most 
important centers of social and political developments in the country over the centuries (Azarpor and Atari, 2010). It has a rich historical background and although it has lost many of its works and attractions in times of natural and man-made disasters such as severe earthquakes, it is still considered one of the richest and most historically valuable cities. Some of these works are Tabriz Citadel, the kabod mosque and the historic Indoor Market with a length of one kilometer recorded on the world heritage list. In addition, other attractions such as museums and crafts, amusement centers and therapeutic facilities are potentials that attract tourists to Tabriz everywhere. The presence of tourist destinations, proper infrastructure, museums, carpet museum, nature, number of historic sites has made Tabriz, the world's largest carpet choice, in terms of its demographic, climatic and migratory status, as well as the most time spent by citizens. The importance of urban tourism planning is further emphasizing the importance of creating and designing recreational areas in the city of Tabriz.

Figure 2: Distribution map of Tabriz recreational tourism center

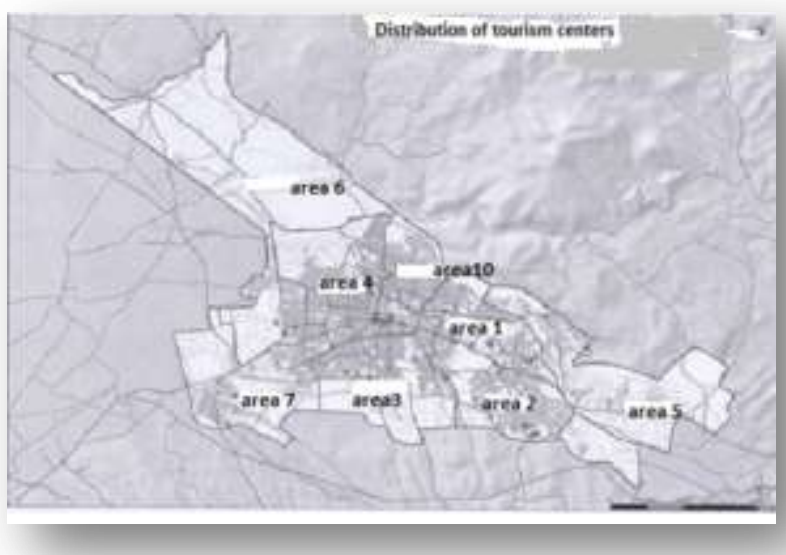

The distinguished historical and cultural status of the Tabriz metropolis is acknowl- edged by the world's tourism activists and islamic tourism organization ministers (at the niger summit in 2015), considering all the capacities and attractions of Tabriz, have set this Islamic city as the capital of Islamic tourism for The year 2018 was introduced.

\subsection{SWOT assessment method}

This model which is presented in strategic planning, is used to analyze the situation and assess the strengths, weaknesses, opportunities and threats to identify strategic issues and provide a suitable solution in the long run (Mahdavi, 2003). This model is a suitable strategy to maximize strengths and opportunities and minimize weaknesses and threats.

Opportunities and threats: exogenous opportunities and threats, events and economic, social, cultural, ecological and environmental flows that can be beneficial or harmful in the future. Strengths and weaknesses: Internal strengths and weaknesses are part of a controllable activity that an organization performs in a very good or very bad way (Fardar, 1382).

Table 1: Matrix affecting the growth of tourism in Tabriz city
\begin{tabular}{|l|l|l|}
\hline Component & Strengths & Weak points \\
\hline & $\begin{array}{l}\text { The presence } \\
\text { of varied and } \\
\text { valuable } \\
\text { handicrafts } \\
\text { such as Tabriz } \\
\text { Economic } \\
\text { carpets and } \\
\text { having the } \\
\text { Tabriz and, consequently, } \\
\text { the monetization of hotel- } \\
\text { related activities in the city }\end{array}$ \\
$\begin{array}{l}\text { proper capac- } \\
\text { ities and } \\
\text { facilities for } \\
\text { the growth of } \\
\text { health tour- } \\
\text { ism such as } \\
\text { the existence } \\
\text { of your aras } \\
\text { archetypes }\end{array}$ \\
\hline
\end{tabular}




\begin{tabular}{|c|c|c|}
\hline & $\begin{array}{l}\text { and special- } \\
\text { ized in the } \\
\text { city of Tabriz }\end{array}$ & \\
\hline $\begin{array}{l}\text { Social and } \\
\text { cultural and } \\
\text { fundamental }\end{array}$ & $\begin{array}{l}\text { The city of } \\
\text { Tabriz is loca- } \\
\text { ted between } \\
\text { the six cultur- } \\
\text { al cities of the } \\
\text { country and } \\
\text { its historical, } \\
\text { religious and } \\
\text { archaeological } \\
\text { backgrounds } \\
\text { such as the } \\
\text { largest indoor } \\
\text { market with } \\
\text { the roof of } \\
\text { the world, the } \\
\text { cultural areas } \\
\text { of customs } \\
\text { and values of } \\
\text { rich anthropo- } \\
\text { logy, the fee- } \\
\text { ling of wel- } \\
\text { coming guests } \\
\text { in the city of } \\
\text { Tabriz, The } \\
\text { presence of } \\
\text { quiet spaces } \\
\text { for tourists } \\
\text { along with } \\
\text { security in the } \\
\text { city, the au- } \\
\text { thorities' beli- } \\
\text { ef in the im- } \\
\text { portance of } \\
\text { the role of } \\
\text { tourism in the } \\
\text { overall } \\
\text { growth of the } \\
\text { city of Tabriz }\end{array}$ & $\begin{array}{l}\text { Failure to observe the } \\
\text { historical context as a } \\
\text { result of the lack of coor- } \\
\text { dination in the manage- } \\
\text { ment and planning of the } \\
\text { city of Tabriz, the limited } \\
\text { attention of officials to the } \\
\text { strengthening and equip- } \\
\text { ping of cultural and artistic } \\
\text { facilities such as cinemas } \\
\text { and showrooms, Lack of } \\
\text { qualified and experienced } \\
\text { staff in hotels } \\
\text { Decreasing beds occupan- } \\
\text { cy rate and hotel rooms in } \\
\text { Tabriz in autumn and } \\
\text { winter, Absence of close } \\
\text { inspection and supervision } \\
\text { of the management and } \\
\text { provision of guest services } \\
\text { in the city of Tabriz, The } \\
\text { lack of promotional pro- } \\
\text { grams in the mass media } \\
\text { and the lack of use of new } \\
\text { promotional tools } \\
\text { The disagreement be- } \\
\text { tween the Cultural Herit- } \\
\text { age and the City Council on } \\
\text { the maintenance and } \\
\text { restoration of the city's } \\
\text { historical context, the lack } \\
\text { of experienced human } \\
\text { resources in tourist places, } \\
\text { the lack of job security, } \\
\text { tourism guidance, the lack } \\
\text { of attention to the role of } \\
\text { tourism in urban develop- } \\
\text { ment plans, the im- } \\
\text { portance of the role of } \\
\text { tourism in urban develop- } \\
\text { ment Between people }\end{array}$ \\
\hline $\begin{array}{l}\text { Spatial, } \\
\text { physical }\end{array}$ & & $\begin{array}{l}\text { Low attention to the or- } \\
\text { ganization and restoration } \\
\text { of the spaces and sur- } \\
\text { rounding areas of the } \\
\text { monuments, the reduction } \\
\text { of the beauty and attrac- } \\
\text { tiveness of these works, } \\
\text { the lack of recreation } \\
\text { spaces inside and around } \\
\text { Tabriz, the high proportion } \\
\text { of hosts to hotels in Tabriz, } \\
\text { attention to the furnishing } \\
\text { and beautifying historical } \\
\text { spaces such as lighting } \\
\text { them, Low attention to } \\
\text { equipping and organizing }\end{array}$ \\
\hline
\end{tabular}

\begin{tabular}{|l|l|l|}
\hline & $\begin{array}{l}\text { urban areas within the } \\
\text { central part and around } \\
\text { the historical market of } \\
\text { Tabriz city }\end{array}$ \\
\hline
\end{tabular}

Considering the complexes of strengths, weaknesses and threats of tourism in Tabriz, the internal factors or the strengths and weaknesses of the tourism city of this city are classified according to the three components of economic, cultural and institutional, as shown in Table 1.

Table 2: matrix of external factors affecting the growth of tourism in Tabriz city

\begin{tabular}{|c|c|c|}
\hline Component & Opportunities & Threats \\
\hline Economic & $\begin{array}{l}\text { Increasing the } \\
\text { incentives of the } \\
\text { private sector to } \\
\text { invest in the } \\
\text { tourism sector, } \\
\text { cooperation bet- } \\
\text { ween ECO coun- } \\
\text { tries in the field } \\
\text { of tourism grow- } \\
\text { th such as visa } \\
\text { waivers between } \\
\text { member coun- } \\
\text { tries, the crea- } \\
\text { tion of ECO tou- } \\
\text { rism websites } \\
\text { and investment } \\
\text { in the tourism } \\
\text { sector, the open- } \\
\text { ing of temporary } \\
\text { and temporary } \\
\text { handicrafts exhi- } \\
\text { bitions in the } \\
\text { city of Tabriz, } \\
\text { the creation of } \\
\text { banks Tourism in } \\
\text { the country and } \\
\text { the opening of } \\
\text { its second bran- } \\
\text { ch after Tehran } \\
\text { in Tabriz, holding } \\
\text { international } \\
\text { conferences and } \\
\text { exhibitions on } \\
\text { investment op- } \\
\text { portunities in } \\
\text { the country, the } \\
\text { growth of com- } \\
\text { panies providing } \\
\text { tourism services } \\
\text { in the country, }\end{array}$ & $\begin{array}{l}\text { Increasing competition } \\
\text { between existing cities } \\
\text { in the region by creat- } \\
\text { ing more facilities and } \\
\text { services aimed at in- } \\
\text { creasing tourism }\end{array}$ \\
\hline
\end{tabular}




\begin{tabular}{|c|c|c|}
\hline & $\begin{array}{l}\text { the existence of } \\
\text { major tourism } \\
\text { markets in Islam- } \\
\text { ic countries }\end{array}$ & \\
\hline $\begin{array}{l}\text { Social, } \\
\text { cultural and } \\
\text { fundamental }\end{array}$ & $\begin{array}{l}\text { Existence of cul- } \\
\text { tural commonal- } \\
\text { ity with neigh- } \\
\text { boring countries } \\
\text { and the exist- } \\
\text { ence of tourism } \\
\text { growth in the } \\
\text { city of Tabriz, } \\
\text { the facilitation of } \\
\text { entry regulations } \\
\text { Tourists from } \\
\text { neighboring co- } \\
\text { untries to the } \\
\text { city of Tabriz, } \\
\text { commence the } \\
\text { operation of the } \\
\text { city train and } \\
\text { facilitate the } \\
\text { transportation of } \\
\text { tourists to his- } \\
\text { toric and ancient } \\
\text { sites, cultural } \\
\text { change and } \\
\text { increased incen- } \\
\text { tives for travel } \\
\text { and tourism } \\
\text { among the peo- } \\
\text { ple. }\end{array}$ & $\begin{array}{l}\text { The existence of dis- } \\
\text { turbing regulations at } \\
\text { the entrance and exit } \\
\text { points of the city, the } \\
\text { increase in the closing } \\
\text { of cinema and drama } \\
\text { houses in the city of } \\
\text { Tabriz or the transfor- } \\
\text { mation of them into } \\
\text { commercial and pas- } \\
\text { sage complexes, the } \\
\text { decline in the number } \\
\text { of Tabriz cinemas in the } \\
\text { past years, the lack of } \\
\text { coordination among } \\
\text { authorities related to } \\
\text { urban management and } \\
\text { sector Tourism for the } \\
\text { effective planning and } \\
\text { management of tour- } \\
\text { ism, the existence of an } \\
\text { unfavorable advertising } \\
\text { space in the interna- } \\
\text { tional arena to create } \\
\text { an unfavorable image } \\
\text { of the Iran. And, conse- } \\
\text { quently, the reduction } \\
\text { of the number of for- } \\
\text { eign tourists, the inse- } \\
\text { curity of tourists due to } \\
\text { the lack or lack of park- } \\
\text { ing in the tourist areas } \\
\text { The central part of the } \\
\text { city and the possibility } \\
\text { of stealing a car or its } \\
\text { accessories }\end{array}$ \\
\hline Situational & $\begin{array}{l}\text { Having potential } \\
\text { natural capaci- } \\
\text { ties in the prov- } \\
\text { ince and Tabriz } \\
\text { city for the } \\
\text { growth of moun- } \\
\text { taineering and } \\
\text { skiing such as } \\
\text { Sahand ski re- } \\
\text { sort, getting on } \\
\text { the route of the } \\
\text { country's rail } \\
\text { connections with } \\
\text { neighboring co- } \\
\text { untries such as } \\
\text { passing Tehran } \\
\text { railway, Ankara } \\
\text { from Tabriz, the } \\
\text { city of Tabriz in } \\
\text { the route of }\end{array}$ & $\begin{array}{l}\text { The intensification of } \\
\text { air pollution in the city } \\
\text { of Tabriz due to diverse } \\
\text { industrial activities and } \\
\ldots \text { Tabriz location in } \\
\text { high risk areas due to } \\
\text { earthquake and the } \\
\text { possibility of earth- } \\
\text { quake, cold zone and } \\
\text { long cold period and a } \\
\text { sharp fall in the number } \\
\text { of tourists in winter, } \\
\text { the existence of points } \\
\text { Incident in the areas of } \\
\text { province communica- } \\
\text { tion and high road } \\
\text { traffic accidents, con- } \\
\text { tinuous drought in the } \\
\text { catchment area of Lake } \\
\text { Urmia and reduction of }\end{array}$ \\
\hline
\end{tabular}

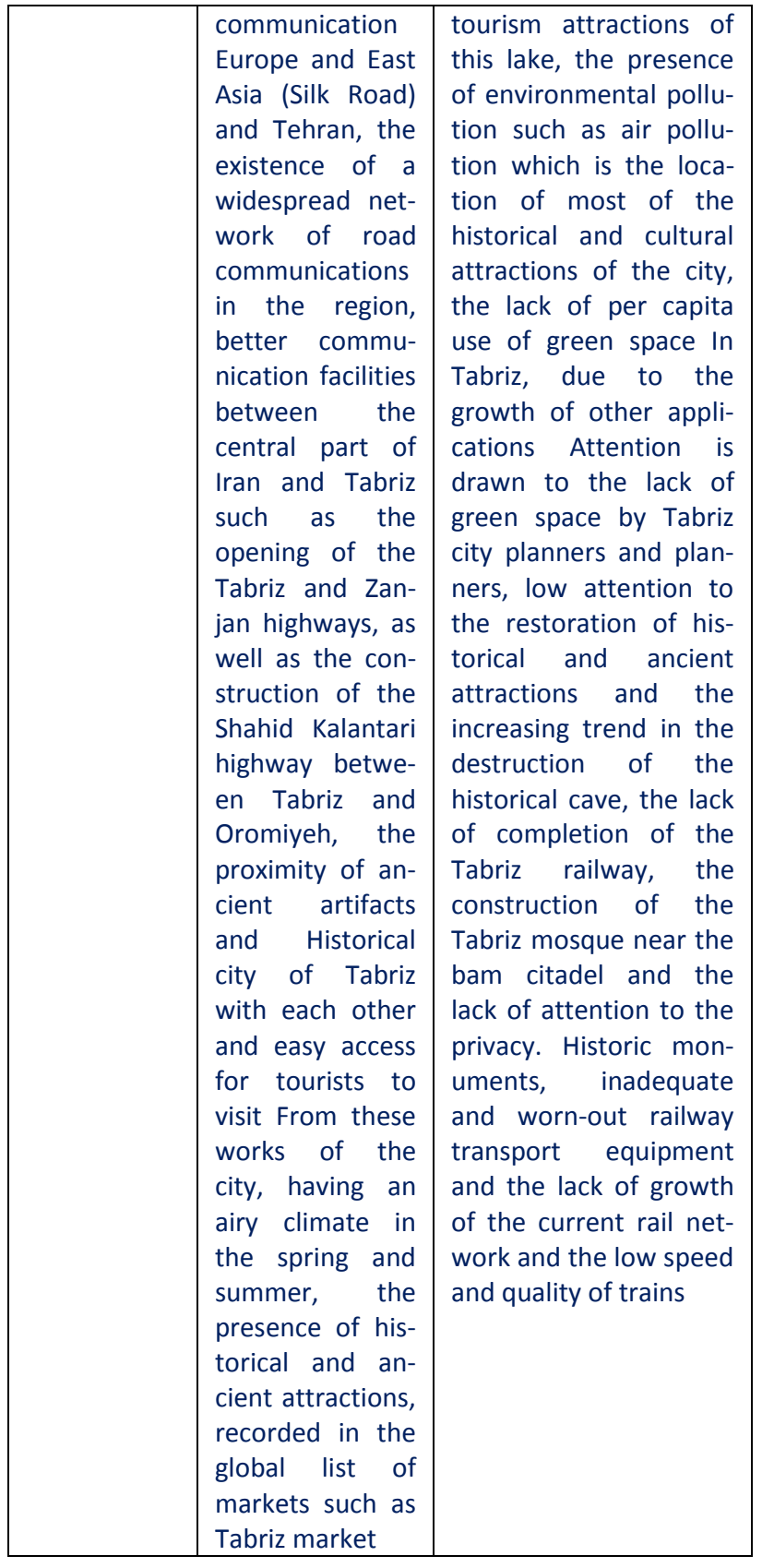

Assessment of strengths, weaknesses, opportunities and threats Tabriz Tourism:

\section{Strengths:}

- There are world-class historical monuments such as the Tabriz bazaar and the azarbayjan churches.

- The diversity of historical and cultural tourism attractions such as historical museums and old houses, etc. 
- There are 46 tourism sample areas approved by the Board of Ministers.

- High biodiversity.

- Variety of water resources (aras beaches oromiyeh lakes etc.)

- Climate variation, altitude and vegetation in this province.

- There are special caves and natural reserves.

- The presence of specialist doctors and treatment centers and diagnosis with a desirable standard.

- Traditional supplement therapy (herbal treatment, water treatment, hejamat, etc.) and the variety of medicinal herbs.

- There are amazing villages with special features (kandavan ashtin, sor, zanozagh, etc).

- The life of the nomadic community with traditional and traditional customs in this province.

- Establishment of Tabriz City on the Silk Road and the privileged position of the Tabriz Market on this road.

- The existence of the free trade and industrial zone aras.

- International exhibition and metropolis of Tabriz as one of the industrial hubs of the country.

\section{Weak points:}

- The lack of a comprehensive marketing and information system

- Weakness in the conservation and restoration of ancient monuments and other attractions.

- The weak coordination of naturalresource-related operating systems.

- The risks of circulation growth in nature, regardless of the sustainability of tourism

- The lack of constant and constant man- agement of health tourism organization.

- Lack of supervision over the implementation of approved tariffs for health and diagnostics provided to health tourists.

- Inadequate education of local communities and hospitality culture

- The lack of private sector investment in rural infrastructure and nomadic tourism.

- Lack of definition of brand for tourism in the province.

- The lack of sufficient and constructive interaction between the private and public sector in the field of tourism.

- The lack of tourism and industrial infrastructure in the aras Free Zone (airport, etc).

\section{Opportunities:}

- Neighborhood of the province with 3 neighboring countries and the existence of common cultural and historical boundaries.

- Position of the province in the tourism and historical axis of the pardisan plan.

- The interest of foreign tourists in visiting the historical attractions of the province and the desire to expand and improve international relations.

- The geographical extent of the aras commercial and industrial zone and the existence of campuses

- Good climate and favorable climate.

- The existence of new habitats and sites.

- The existence of research potential in the field.

- The desire of the people of the neighboring countries to use the health services of the province.

- The presence of therapeutic tourism attractions such as spa springs, mud therapy and health villages.

- Familiarity and recognition of foreign tourists from the village of Kandavan as a 
tourism destination and their desire to travel to it and other villages of tourism destination.

- There are many areas of extensive investment in health tourism in the province.

- Economic links with a population of 300 million ECO members.

- The proper geographic location of the province in the area of transit of goods and passengers to neighboring countries.

- There are 50 large industrial plants in the province.

\section{Threats:}

- The continuation of international sanctions against our country which increases costs and reduces the quality of services.

- The presentation of the irresponsible face of the Islamic Republic of Iran's Islamic system on international networks

- Inactivity of tourism service companies in foreign countries.

- Urban growth and new construction in the historical context.

Increasing pollution and spreading salt dust.

- The dryness of the Urmia- Lake and its widespread issues.

- Competition of some countries in the region by the construction of medical centers and the recruitment of Iranian and foreign forces.

- The spread of contagious diseases by foreign health tourists.

- The inadequacy of public opinion for the acceptance of health tourists.

- Incompatibility of domestic tourism policies with international tourism slogans and policies.

- The promotion and promotion of modern architecture and traditional architectural forgetting in the villages of tourism desti- nation.

- Absence of our country in the World Trade Organization.

- Creation and growth of free zones with the approach of tourism in neighboring countries.

- Failure to define and define criteria related to the attraction of foreign tourism.

- Parallel work and lack of cooperation and coordination of public and private executive agencies to attract foreign investment.

- Restrictions on government credits.

- Lack of access to international currency transfer networks and inefficiency of international credit cards in the country.

- The lack of a specific place for changing the foreign currencies of tourists to real.

\section{CONCLUSIONS}

Today, tourism, as one of the industries of sustainable growth, creates great economic, cultural and social opportunities for major global cities such as the great Iran. This industry has a great influence on the spatial structure of the Iran cities. Today, urban tourism has become a competitive process in any society in the major cities of the country which can be used to increase the tourist's host through coherent management of investment within the city. However, it is not possible to accurately and precisely illustrate a sustainable city in this regard and thus precisely define the solutions to achieve it. The Sustainable City forms a widespread process that provides the mentality of promoting solidarity, the social and economic well-being of its native city and region and realizing this mentality and opportunity. We now recognize the importance of tourism as an important hu- 
man activity that has different economic, social, cultural and environmental dimensions.

In fact, sustainable growth in meeting the needs of the present and future generations must be in a way that, in addition to preserving cultural identity and identity, it can provide the residents with a balanced balance of health and well-being. With a logical link, tourism and sustainable growth can be linked which does not just address the needs of today's generation and work fairly in the current and future generations and pursue the motto of "green tourism" or "sustainable tourism". Here, we must admit that the phenomenon of sustainability is not an ideal, but a necessity.

Tabriz is one of the 6 most historic and cultural cities in the country and is considered the fourth most populous city in the country. The city of Tabriz, like other Iran cities, has many potentialities for tourism growth, but it has many problems and obstacles despite its high growth potential. Nevertheless, tourism is often seen as one of the growth options against emerging countries and regions. Sustainable growth of tourism in social and cultural dimensions, improving quality of life, establishing community-based management organizations, encouraging the acceptance of cultural differences and institutionalizing growth in local culture. Among the historic and important cities of Iran, the city of Tabriz can be considered as one of the most suitable options for planning and implementing urban tourism, in which case a wide range of activities such as employment, sustainable income for municipalities, diversification of the economy a city supporting investment, preservation and restoration of historical and traditional monuments and so on.

\section{REFERENCES}

ABBASI, M.R. et al, Challenges and solutions of Iran's Tourism Industry, Trade studies, V. 53: 72-85, 2012.

AZARPOR, R.; ATARI, M. what is going on the Arg-Alishah of Tabriz. Architecture and Building Quarterly, 13:112-116, 2010. Commission on sustainable Development. Tourism and sustainable development: a local authority perspective. $7^{\text {th }}$ session, New York, 1999.

DAKHILI KAHNAMOYI, J.; The study of strategies for tourism industry development in East Azarbayjan. Master's thesis of geographic group and planning. Tabriz University, Tabriz, 2004.

FARDAR, D.; Strategic Management, Translation by Ali parsayian and Seyyed Mohammad Arabi, Tehran. Publication of Office of cultural Research , 2003.

GANTLY, F.; tourism Impact in Azerbaijan: A socio Cultural Analysis, Ph.D. Thesis presented to the faculty of tourism and food, Dublin institute of technology, Dublin, 2007.

GRABURN H., NELSON H, JAFARI, J. Introduction: Tourism social science, Annals of Tourism Research, Volume 18, Issue1, pages 1-11, 1991. https://doi.org/10.1016/016 0-7383(91)90035-A

Heidary, R. Fundamentals of planning tourism industry, publication Samt, Tehran. 2008.

MAHDAVI, D. Strategic Management, translation by Ali Parsayian and Seyyed Mohammad Arabi, Tehran, office of cultural Research.118, 2003.

NOBAKHT, M.B.; PIROUZ, E. Development of Tourism in Iran: Barriers and Solutions, Research Branch of Islamic Azad University (in Persian), 2008. 
RAKHSHANY NASAB A., ZARABY A.; Geographic space, No 28:41-55, Isfahan University Press, Isfahan , 2009.

SHOJAEAY, M , NORY N;. The study of government policies in the tourism industry and the presentation of sustainable tourism development model of the country's tourism industry. Management knowledge, Vol: 78, page 90-63, 2007.

UNWTO.; Yearbook of tourism statistics. Madrid: World Tourism organization, 2012. Available online: http://cf.cdn.unwto.org/si tes/all/files/pdf/annual_report_2012.pdf

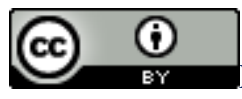

License information: This is an openaccess article distributed under the terms of the Creative Commons Attribution License, which permits unrestricted use, distribution, and reproduction in any medium, provided the original work is properly cited.

Article received on December 28, 2017.

Evaluated January 29, 2018

Accepted on January 30, 2018.

Published on May 25, 2018.

\section{How cite this article (ABNT):}

GOLZARI, Sepideh Gorbaniye; DALIR, Karim Hosseinzadeh; BABAYI, Bashir Beyg. Assessing the current problems in the tourism industry (case study: Tabriz city). Estação Científica (UNIFAP), Macapá, v. 8, n. 1, p. 81-90, jan./abr. 2018. 